\author{
УДК 021.2:[002.1:908]:004 \\ DOI: $10.31866 / 2616-7654.8 .2021 .247586$

\section{КРАЄЗНАВЧI ЕЛЕКТРОННІ РЕСУРСИ В ОСВІТНЬОМУ ПРОЦЕСІ} \\ Євген Забіянов, \\ провідний бібліотекар \\ Одеської обласної універсальної наукової \\ бібліотеки ім. М. С. Грушевського \\ (Одеса, Україна) \\ e-mail: j_zb@ukr.net \\ ORCID: 0000-0002-4959-9099
}

Цифровізація та медіатизація інформації актуалізує питання доступу користувачів до електронних інформаційних ресурсів. В умовах потреби формування і зміцнення регіональної та національної ідентичності суспільної ваги набувають також вивчення та популяризація інформації історико-краєзнавчого характеру і забезпечення доступу до неї, інтеграція такої інформації в освітні практики з метою опанування нею молоддю.

Стаття присвячена висвітленню та обгрунтуванню ефективних підходів до використання краєзнавчих електронних ресурсів в освітньому процесі.

Під час дослідження використані описовий метод, методи порівняння та узагальнення стосовно досвіду використання у сфері освіти краєзнавчих електронних ресурсів бібліотек. Ефективними виявились методи включеного спостереження та періодичного моніторингу, застосовані під час розробки та підтримки функціонування за участю автора краєзнавчого ресурсу «Краевед» (kraeved.od.ua) (починаючи з 15.03.2020р.). Для аналізу наявного теоретичного доробку за темою дослідження застосовувався аналітично-оглядовий метод.

Новизна отриманих результатівполягає у висвітленні й обгрунтуванні специфіки використання в освітньому процесі в різних країнах світу електронних краєзнавчих інформаційних ресурсів, зокрема під час навчання студентів історичних спеціальностей, а в деяких країнах - студентів, які навчаються за спеціальностями культурології та мистецтвознавства. Найбільш комплексно електронні краєзнавчі інформаційні ресурси використовуються у США, де їх історико-краєзнавчий контент приваблює не лише викладачів та студентів, а й ширше коло користувачів: дослідників генеалогії, письменників, інженерів, містобудівників, архітекторів, ріелторів та режисерів документальних фільмів.

Отримані результати дослідження засвідчили тенденцію до використання бібліотечних краєзнавчих електронних інформаційних ресурсів у освітньому процесі. Їх створення, зацікавленість користувачів у представленій на них інформації та ііі використанні під час навчання засвідчують важливість краєзнавчого контенту, покликаного сприяти формуванню історико-культурної ідентичності регіону в контексті історії країни та формуванню національної історичної пам'яті в органічному поєднанні з розвитком історичної думки. Узагальнення зарубіжного досвіду та перспективних вітчизняних практик використання в освітньому процесі краєзнавчих електронних бібліотечних ресурсів дає змогу обгрунтувати ефективні підходи до організації такої діяльності, активізації залучення вітчизняних бібліотечних краєзнавчих електронних інформаційних ресурсів до вирішення інформаційних задач, пов’язаних з освітньою діяльністю. Інтенсивний розвиток цифрових бібліотечних проєктів в освітньому середовищі відкриє додаткові шляхи для реалізації завдань бібліотек із забезпечення широкого доступу користувачів до краєзнавчих інформаційних джерел та максимального розкриття їх інформаційного потенціалу.

Ключові слова: краєзнавчі електронні ресурси, інформаційно-освітній процес, краєзнавчий контент, заклади освіти, національна історична пам'ять, історико-культурна ідентичність регіону. 
Український журнал з бібліотекознавства та інформаційних наук. Випуск 8 (2021) Ukrainian Journal on Library and Information Science. Issue 8 (2021)

\section{ВСТУП}

Одним із впливових чинників освітніх трансформацій в епоху цифровізації, комп’ютеризації та медіатизації є бібліотечні електронні інформаційні ресурси, значимість яких зумовлюється зростанням кількості генерованих людством інформації та знань і потребою їх збереження, ефективної організації, надання до них доступу, сприяння їх введенню в широкий суспільний обіг.

Бібліотечні електронні інформаційні ресурси покликані сприяти вирішенню проблеми забезпечення рівного доступу до інформації, що створює умови для демократизації системи освіти, активному введенню в науковий обіг нових знань і розвитку в такий спосіб теоретичного підгрунтя освітніх практик. Адже, «можливість мати доступ до результатів наукової діяльності та їх поширення для всіх рівнів зацікавлених користувачів є великою цінністю суспільства» (Островська, 2020, с. 217).

Зі свого боку, краєзнавча інформаційна складова бібліотечних електронних інформаційних ресурсів спрямована на збереження культурної національної пам'яті (культурна пам'ять нації) як виду історичної пам’яті, формування регіональної ідентичності, що є компонентом становлення самобутності і суб'єктності суспільства та держави, особливо в умовах інформаційного протистояння, обумовлених сучасними конфліктами.

Метою дослідження $є$ висвітлення і обгрунтування ефективних підходів до залучення бібліотечних краєзнавчих електронних ресурсів в освітній процес.

\section{ТЕОРЕТИЧНЕ ПІДГРРУНТЯ}

Для реалізації поставленої мети було опрацьовано фахові наукові публікації, що стосуються, по-перше, функціонування бібліотечних електронних ресурсів, по-друге, - використання бібліотечних електронних ресурсів у наукових установах та навчальних закладах, по-третє, - краєзнавчої діяльності бібліотек в умовах електронного середовища та системного формування краєзнавчих електронних ресурсів.

Електронні ресурси бібліотек як атрибут інформаційного суспільства та питання інтеграції їх у єдиний інфопростір розглянуто у працях О. С. Оніщенка, В. М. Горового, В. І. Попика (Тенденції впливу, 2013), Н. П. Пасмор (2014, 2019), К. Лобузіної (2012), І. Лобузіна (2016), Д. Соловяненка (2003), О. Каращук (2016), T. Ярошенко (2008), H. Yu \& S. Breivold (2008), J. Zellers, T. M. Adams \& K. Hill (2018). Більшість науковців акцентують збільшення ролі бібліотечних інформаційних ресурсів у генерації інтелектуального потенціалу суспільства (Тенденції впливу, 2013; Пасмор, 2014; Соловяненко, 2003; Zellers et al., 2018), адже «зміни у технологічних циклах сприяють удосконаленню традиційних та пошуку нових форм обслуговування читачів» (Новальська, 2007, с. 24), що виводить таке обслуговування на новий рівень і створює технологічний базис для ефективного використання наявних інформації та знань. При цьому, якщо К. Лобузіна (2012) зосереджує увагу на бібліотечних інформаційних ресурсах у контексті соціокомунікаційних процесів та формування суспільства знань, розкриваючи шляхи вирішення проблеми актуалізації та інтелектуального доступу до масивів історико-культурної і наукової інформації, то І. Лобузін (2016) розглядає приклади реалізації бібліотечних цифрових проєктів оцифрування історико-культурного та наукового надбання та організації бібліотечних цифрових технологічних комплексів. 
Зі свого боку, Т. Ярошенко (2008), Н. Yu \& S. Breivold (2008) обгрунтовують роль і статус бібліотеки в інформаційному суспільстві завдяки її можливостям здійснювати кумуляцію, обробку, збереження та організацію доступу до онлайнових електронних ресурсів: електронних журналів, електронних книг, повнотекстових баз даних, цілісних електронних бібліотек тощо.

Тенденціям використання електронних бібліотечних ресурсів у наукових установах та навчальних закладах присвячено низку праць таких вітчизняних і зарубіжних учених-теоретиків та практиків, як I. О. Беззуб (2015), С. М. Іванова (2011, 2019), Я. В. Топольник (2017), Л. М. Бондар (2015), О. А. Кучерук (2018), Л. I. Скрипка (2016), J. M. Mendel (1999), S. K. Sonker \& K. L. Mahawar (2017), Д. Бейнбридж, И. Виттен, Д. Николс (2007) та ін. Аналізуючи можливості освіти на базі нових інформаційних технологій, більшість вчених погоджуються, що електронні бібліотечні ресурси на сьогодні стають невід’ємною частиною інформаційно-освітнього середовища (Топольник, 2017, с. 188; Бондар та ін., 2015, с. 45; Скрипка та ін., 2016, с. 112) та є суттєвим доповненням до цифрового середовища навчання (Іванова, 2011; Кучерук та ін., 2018, с. 161).

При цьому поза увагою дослідників залишається аспект використання в освітньому процесі краєзнавчих електронних ресурсів, що мають свій потенціал, здатнийдодати нові грані і «революціонізувати освіту та навчання» (Mendel, 1999, p. 13).

Низка науковців, а саме Н. Кушнаренко (2005), В. Кисельова (2019), М. Кузнецова (2009), Н. Литвиненко (2009), С. Денисенко (2003) та ін., порушували у своїх дослідженнях питання краєзнавчої діяльності бібліотек в умовах електронного середовища та системного формування бібліотечних краєзнавчих електронних ресурсів. Як зазначила Н. Кушнаренко (2005), технологічна модернізація створює сприятливі умови переходу від традиційної до електронної парадигми розвитку краєзнавчої діяльності бібліотек (с. 4). Зі свого боку, Н. Литвиненко (2009) наголошує на тому, що перспективним напрямом є організація краєзнавчої електронної бібліотеки (с. 41). 3 огляду на те, що формування бібліотечних електронних ресурсів із краєзнавства створює важливу документально-інформаційну базу для широкого загалу користувачів (Кузнецова, 2009, с. 28), О. Чала (2017) порушує питання про систему підготовки майбутніх учителів до використання нових аспектів краєзнавчого потенціалу в освітньому процесі (с. 268).

Водночас аналіз публікацій із використання цифрових бібліотечних проєктів угалузі освіти виявив, що комплексного вивчення ролі саме бібліотечних краєзнавчих електронних ресурсів у освітньому процесі не проводилося, що засвідчує актуальність визначеної для дослідження мети висвітлитиі обгрунтувати ефективні підходидо використання бібліотечних краєзнавчих електронних ресурсів в освітньому процесі. Зважаючи навідсутність правдивої і повної інформації про стан інформатизації в бібліотеках України (Бруй, 2021), вивчення інноваційного зарубіжного та вітчизняного досвіду у царині використання бібліотечних краєзнавчих ресурсів у освітньому процесі дасть змогу розкрити наявні ефективні підходи до інтеграції краєзнавчого матеріалу в освітні практики, обгрунтувати перспективний напрям краєзнавчої роботи вітчизняних бібліотек.

\section{МЕТОДИ І МАТЕРІАЛИ}

У дослідженні були застосовані методи порівняння та узагальнення наявних практик використання у сфері освіти краєзнавчих електронних ресурсів бібліо- 
тек. Джерелами для аналізу було обрано офіційні веб-сайти закладів вищої освіти та їх наукових бібліотек таких країн, як США, Японія, Малайзія. Зокрема, краєзнавчі електронні ресурси «Cherokee County Digital History Project» Університету штату Джорджія (округ Черокі) та «Historic Pittsburgh» Університету Пітсбурга (США), а також «HUMI» Університету Кейо (Японія) та «CoreDev» Університету Малайя (Малайзія). Для реалізації мети і отримання результатів дослідження ефективними виявилисяметоди систематичного (щоденного) контент-моніторингу та метод включеного спостереження стосовно краєзнавчого ресурсу «Kraeved» громадської організації «Краєвєд» (Одеса, Україна), оскільки автор із 03.09.2015 р. $є$ одним із розробників і учасників підготовки контенту та забезпечення функціонування цього ресурсу. Ключовим методом для опрацювання наявних теоретичних здобутків за темою дослідження став оглядово-аналітичний метод.

\section{РЕЗУЛЬТАТИ ДОСЛІДЖЕННЯ}

Розширення видової багатоманітності і тематики електронних інформаційних ресурсів $є$ необхідною умовою інформаційного забезпеченняосвітнього процесу в сучасних умовах поширення інтернет-технологій. Інтеграція електронних інформаційних ресурсів у сферу освіти створює підгрунтя для розширення доступу до більш різноманітних та нестандартних її форм. При цьому вони мають позитивний вплив натрансформацію навчальних просторів, у яких застосовуються цифрові технології для підтримки кожного, хто здобуває освіту (Коваль \& Лопата, 2021, с. 7).

Цифрова інтеграція електронних ресурсів сприяє посиленню ролі бібліотек як важливої складової інформаційної інфраструктури процесу системи навчання та наукової діяльності.

Зокрема, більшість європейських країн, США та країн Азії серед пріоритетних напрямів інноваційного розвитку освіти визначають для себе формування і наповнення цифрових бібліотек як стратегічно важливе завдання для підвищення якості й доступності освіти, а також для створення нових конкурентних переваг системи освіти (Беззуб, 2015, с. 486).

Компонентом системи бібліотечних електронних ресурсів, використання яких увійшло в освітні практики, є краєзнавчі електронні ресурси.

Так, цифровий краєзнавчий та історико-культурнийконтент було успішно інтегровано в освітній курс «Europeana in your classroom: building 21st-century competences with digital cultural heritage» длястудентів різних рівнів у межах проєкту European Schoolnet Academy (Іванова \& Новицька, 2019, с. 90). Розробники курсу знайомлять студентів із платформою Europeana, що була визначена головною європейською е-бібліотекою та загальноєвропейським інтегратором цифрових культурних матеріалів (Рибачок, 2017, с. 11).

Традиційно вважається, що інформаційні ресурси краєзнавчого характеру можуть бути ефективно використані під час вивчення історії, літератури, культури загалом, тобто в галузі гуманітарних дисциплін. Проте такі ресурсиможуть надати ілюстративний матеріал і для викладання інженерної справи, прикладних та математичних наук. При цьому курс «Europeana in your classroom: building 21st-century competences with digital cultural heritage» пропонує добірку перевірених навчальних занять та краєзнавчих електронних ресурсів різних європейських країн, даючи 
змогу розширити можливості вчителів початкових і середніх класів щодо залучення учнів до культурної спадщини в класі ("Welcome to the "Europeana", 2020).

Краєзнавчі електронні ресурси відкривають працівникам сфери освіти додатковий спектр можливостей. Вони можуть включати в себе різноформатний контент (книги, журнали і газети, фотографії, карти та плани, архівні документи, відео- та аудіовізуальні матеріали та ін.) і функціонувати навіть як віртуальні лабораторії (Бейнбридж и др., 2007, с. 42).

Комплексний підхід для використання краєзнавчих електронних ресурсів у освітньому процесі реалізований у різних закладах вищої освіти США. Краєзнавство тут здебільшого розглядається як елемент навчальних програм з історії США чи всесвітньої історії. Воно дає змогу студентам підключитися до вивчення місцевої історії, що створює сприятливий грунт для покращення здатності студентів контекстуалізувати своє історичне мислення (Clarke \& Lee, 2004, p. 84).

Враховуючи, що краєзнавство завжди відігравало важливу роль у суспільних дослідженнях, а вивчення місцевої історії дає студентам змістовний та достовірний контекст, у якому вони можуть використовувати первинні історичні джерела для побудови розуміння взаємозв'язку між місцевими, національними та глобальними подіями, в Університеті штату Джорджія (округ Черокі) спеціалістами з освітніх програм було розроблено оригінальний цифровий краєзнавчий ресурс «Cherokee County Digital History Project». Створений у підсумку ресурс засвідчує корисність технології як інструменту сприяння освіті у разі, коли така технологія використовується разом із відповідним змістовним наповненням (Lee \& Molebash, 2004, p. 155).

Уведений у педагогічну практику краєзнавчий електронний ресурс містить широкий спектр матеріалів, які є цінними для проведення історичних досліджень. Основу контенту е-бібліотеки становлять посібники з історії, картографічні матеріали, архівні джерела, зображення тощо. Цифрові копії першоджерел дають змогу студентам вдосконалювати навички історичних інтерпретацій, які б відповідали їхньому розумінню місцевої історії. Так, завдяки картографічним матеріалам студенти мають змогу сформувати уявлення про історію географії краю. Просторове представлення розташування об’єктів нерухомості на картах уможливлює визначення закономірностей зростання округу Черокі з моменту його заснування досьогодення. Оцінка колекції особистих листів, написаних мешканцями округу на початку XX століття, допомагає реконструювати життя і побут сімей та стосунки у родинах.Завдяки цифровій колекції майна будівель, що мають певну історичну цінність в окрузі, звітів про нерухомість, які супроводжуються фотографіями об’єктів, а також архітектурним даним про будівлі (наприклад, коли їх було побудовано, ким, якими будівельними матеріалами, архітектурним стилем тощо), а також біографічним відомостям про відомих мешканців, студенти можуть дізнатися, які типи житла були типовими для різних соціальних груп людей і як це змінилося протягом XIX-XX століть (Lee \& Molebash, 2004, p. 156).

Зважаючи на активізацію використання під час навчання саме електронних інформаційних джерел, розробники краєзнавчого електронного ресурсу приділяють більше часу організації його контенту та будують свої принципи роботи згідно з тим, що:

- $\quad$ контент ресурсу повинен бути добре організованим та відповідати концепції е-бібліотеки; 
Український журнал з бібліотекознавства та інформаційних наук. Випуск 8 (2021) Ukrainian Journal on Library and Information Science. Issue 8 (2021)

- $\quad$ контент має бути різноманітним;

- ресурс повинен ефективно задовольняти інформаційні запити користувачів.

У результаті ресурс «Cherokee County Digital History Project» став затребуваним інформаційним джерелом, щосприяло його використанню під час підготовки вчителів та запровадження онлайн-формнавчання з використанням цифрових краєзнавчих ресурсів.

Досвід іншої краєзнавчої електронної бібліотеки «Historic Pittsburgh» (див. рис. 1) - це еволюція переходу від невеликого пілотного проєкту до одного з найкращих краєзнавчих ресурсів США прикладного характеру.

3 моменту свого створення ресурс привернув увагу краєзнавців, викладачів та студентів. Основу цифрового різноманіття для навчання забезпечили матеріали факультетів та кафедр Університету Пітсбурга, а також місцевих організацій, які опікуються культурною спадщиною. На сьогодні «Historic Pittsburgh» може запропонувати унікальну джерельну цифрову базу для вчителів, які викладають історію Америки на різних рівнях освіти. Краєзнавча електронна бібліотека поєднує різноманітні цифрові документи, що стимулює інтерес студентів та сприяє більш активному навчанню (Galloway, 2005). Формування контенту відбувається завдяки співпраці з викладачами, які допомагають розробникам зорієнтуватись у виборі відповідних історичних матеріалів для оцифрування.
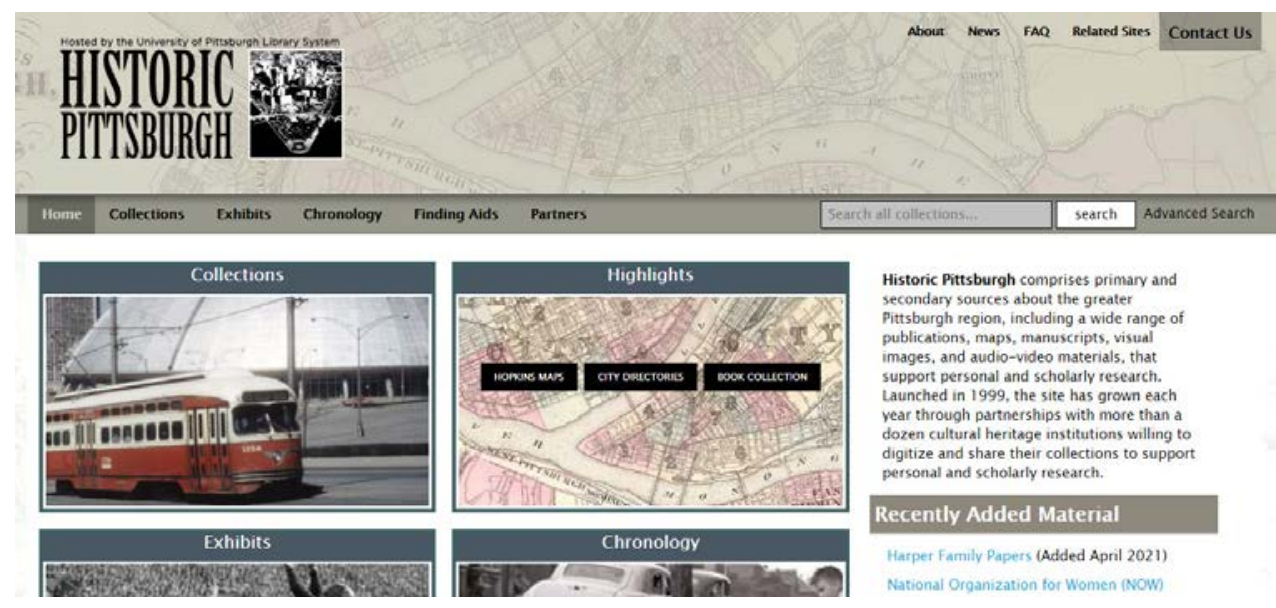

Puc. 1. Краєзнавча електронна бібліотека «Historic Pittsburgh», Університету Пітсбурга. Джерело: https://historicpittsburgh.org/.

Інтеграція до навчальних програм та орієнтація на дослідницькі потребиз вивчення регіональної історіїпозитивно позначились наоцифруванні різноманітних історичних та краєзнавчих матеріалів. Своєю чергою розширення видів контенту завдяки поповненню історичними зображеннями та фотоматеріалами посилило інформаційний потенціал «Historic Pittsburgh» як інструменту онлайн-досліджень (Galloway, 2004). 
Проведені опитування виявили, що краєзнавчий ресурс почав приваблювати не лише викладачів та їх студентів, а й широке коло користувачів: дослідників генеалогії, істориків, письменників, інженерів, містобудівників, архітекторів, ріелторів і режисерів документальних фільмів.

На сьогодні «Historic Pittsburgh» задовольняє потреби широкого кола користувачів і є невід’ємним компонентом інноваційних змін у сучасному навчанні та дослідженнях.

Акцент на використанні унікальностіконтенту цифрових бібліотек у сфері освітиспостерігається сьогодні в Японії. Переведення інформації в цифрову форму - це технологічний переворот, який має великий вплив на викладання та дослідження, а також на передачу та набуття знань. Тому за станом оцифрування можна, зокрема, оцінити науковий потенціал дослідницької спільноти (Nartschik, 2006, p. 199). Для створення середовища, де дослідники вже ефективно використовують комп’ютерні мережі та технології віртуальної реальності, в Університеті Кейо було розроблено проєкт історичного і краєзнавчого напрямку «HUMI» (Humanities Media Interface Project), який був започаткований з метою оцифрування рідкісних книг та рукописівіз колекцій бібліотеки університету (див. рис. 2). В рамках проєкту створено електронну бібліотеку, що обслуговує студентів і дослідників гуманітарних наук, зокрема в галузі літератури, мистецтва та історії. Проєкт «HUMI» був підтриманий Міністерством освіти, науки, спорту і культури та Агентством із промоції інформаційних технологій.

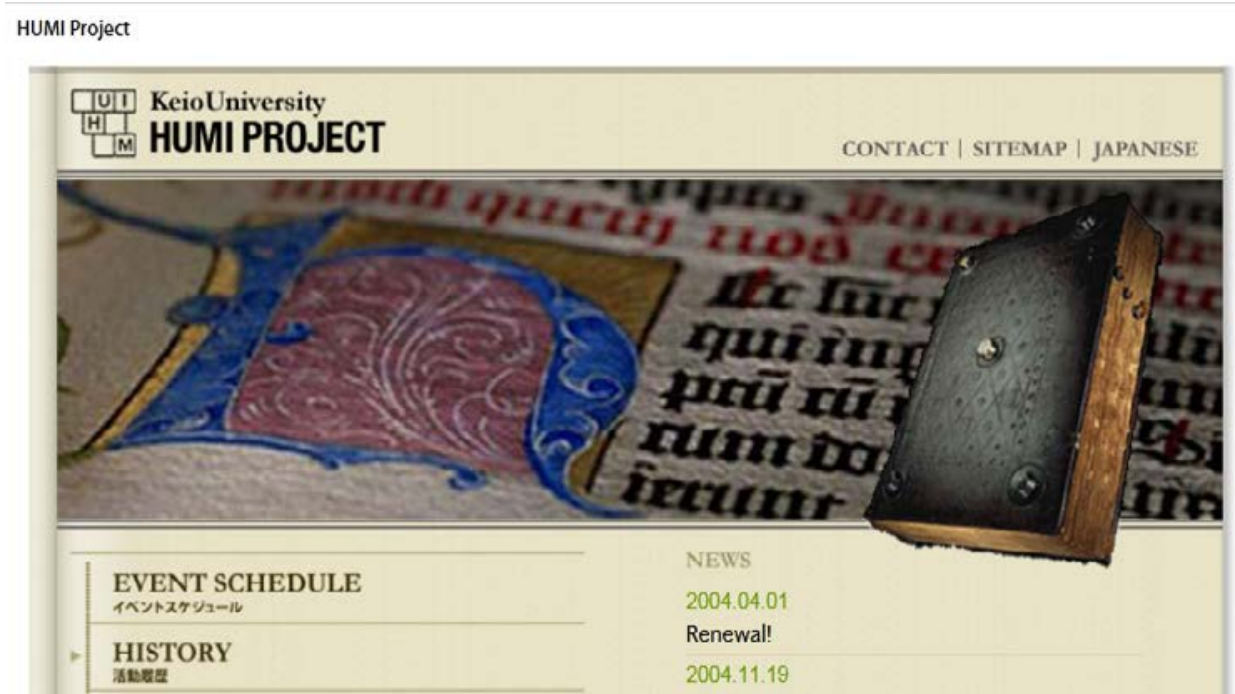

Puc. 2. Інтерфейс проєкту «HUMI» (Humanities Media Interface Project) Університету Кейо. Джерело: https://cutt.ly/lRRSowl.

Окрім того, Університет Кейо дотримується позиції, що важливо надавати доступ до оцифрованих документів історико-культурної спадщини не лише країн Східного регіону, а і Західної цивілізаційної традиції (Mendel, 1999, р. 19). Тому, 
Український журнал з бібліотекознавства та інформаційних наук. Випуск 8 (2021) Ukrainian Journal on Library and Information Science. Issue 8 (2021)

для поповнення контенту електронної бібліотеки придбаваютьсярідкісні книги з усього світу.

Автори історичного та краєзнавчого проєкту виходять із того, що у кіберпросторікнига отримує нове життя, «адже в реальному світі рідкісні книги часто недоступні. Це означає, що оцифровані рідкісні книги ніколи не стануть забутими реліктами минулого. Вони оживають щоразу, коли хтось має до них доступ. Отже, це є сенс реалізації HUMI» (Nartschik, 2006, p. 193).

Значні фінансові та технологічні зусилля, які витрачаються на виробництво якісного цифрового контенту, відповідають потребам значної кількості японських дослідників (Nartschik, 2006, p. 200). Водночас, високий рівень отриманих результатів був гідно оцінений і за межами Японії під час реалізації в рамках проєкту «НUMI» міжнародних партнерських програм.

Пілотний проєкт зі створення спільної цифрової бібліотеки історико-краєзнавчих ресурсів для шкільного навчання був реалізований, також, у Малайзії. Проєкт під назвою CoreDev (Collaborative Resource Development), був ініційований факультетом комп’ютерних наук та інформаційних технологій Університету Малайї і отримав грант від Міністерства науки, технологій та інновацій Малайзії. Його метою було визначенокооперативне створення історично-краєзнавчогоресурсу-збирання, збереження, організація інформації та цифрових джерел з історії Малайзії та надання до них легкого доступу на всіх рівнях середньої освіти (Abrizah \& Zainab, 2004, р. 335). Колекцію електронних документів різних типів і форматів становлять текстові історичні джерела, зображення, аудіо- та відеоматеріали, а також посилання на відповідні тематичні веб-сайти.

Поштовхом до створення такої електронної бібліотеки стало виявлення фактів переважного використаннями студентами для отримання інформації з історії, географії та краєзнавчих пошуків ресурсів інтернету (Abrizah \& Zainab, 2004, p. 335). Тож створення авторитетного інтернет-ресурсу мало на меті надати користувачам доступ до достовірної значущої інформації у зручний для них спосіб. Розроблений цифровий проєкт призначений для підтримки освітнього процесу і наукових дослідженьі може бути використаний різними зацікавленими сторонами - як студентами під час виконання навчальних завдань і досліджень, так і викладачами для підготовки лекційних і практичних завдань і в межах дослідницької діяльності. Ядром партнерства створеної електронної бібліотеки стала співпраця викладачів, які аналізуютьісторичні матеріали та оцінюють історико-культурні фонди, і студентів як контент-менеджерів (Abrizah \& Zainab, 2004, p. 335).

Як засвідчило вивчення думки користувацької аудиторії створеної історично-краєзнавчої електронної бібліотеки, реалізований проєкт досяг своєї мети у підсумкукористувачі отримали зручний і корисний ресурс як з огляду візуального представлення розміщених матеріалів, так із позиції їх організації та надання до них інтуїтивно зрозумілого доступу. При цьому було висловлено ряд корисних зауважень і пропозицій щодо якості самого контенту.

В Україні розвиток краєзнавчого напряму є традиційним для публічних бібліотек. Як показують результати проведеного Національною історичною бібліотекою України в 2019 р. дослідження сучасної організаційної структури та кадрового забезпечення краєзнавчої діяльності у регіональних бібліотеках України (Краєзнавча робота, 2019), «регіональні книгозбірні послідовно розвивають елек- 
тронні бібліотечні ресурси краєзнавчої тематики: ведуть краєзнавчі електронні каталоги та бази даних, створюють Е-бібліотеки та Е-колекції, що включають такі види повнотекстових електронних краєзнавчих документів: краєзнавчі видання $з$ рідкісних фондів бібліотек, краєзнавча література і видання місцевих авторів, видання бібліотеки краєзнавчого спрямування» (с. 45-46). Станом на 2019 р. 19 обласних універсальних наукових бібліотек України, що становить 82\% від їхньої загальної кількості, розміщують на своїх сайтах електронні бібліотеки, які містять повнотекстові краєзнавчі документи, зокрема і ті, що не мають друкованого аналогу у фонді бібліотеки (Краєзнавча робота, 2019, с. 32).

При цьому наголошується на потребі налагодження бібліотеками партнерських зв’язків і корпоративної взаємодії для розвитку краєзнавчих електронних ресурсів та активізації включення представленої на них інформації в широкий суспільний обіг (Дікунова, 2020, с. 6). Згідно з отриманими Національною історичною бібліотекою України в 2019 р. даними, «найпопулярнішим видомспівпраці <...> залишається партнерство бібліотек із закладами культури - музеями, будинками культури, будинками творчості, театрами, школами, мистецькими навчальними закладами усіх рівнів акредитації, а також партнерство з політичними партіями, громадськими організаціями, краєзнавчими спілками, національними товариствами тощо. Мета такого партнерства - проведення різноманітних спільних заходів, випуск спільних інформаційних продуктів, популяризація краєзнавчих, культурних та мистецьких надбань регіону тощо» (Краєзнавча робота, 2019, c. 41). Водночас, зважаючи на наявний позитивний зарубіжний досвід, потребує активізації співпраця вітчизняних бібліотек у напрямі інтеграції накопиченої інформації краєзнавчого характеру в освітній процес із закладами освіти не лише мистецького спрямування.

На користь можливості і перспективності такої співпраці свідчить досвід організації та інтеграції в освітній інформаційний простір Одеського регіону краєзнавчої електронної бібліотеки громадської організації «Краєвєд» (kraeved. od.ua). Проєкт комплексного інтернет-ресурсу краєзнавчого спрямування реалізовувався у допомогу дослідникам, для популяризації і збереження історії Одеського краю. Навколо реалізації проєкту відбулася колаборація представників закладів освіти (а саме Одеського національного університету ім. I. І. Мечникова та Ізмаїльського інституту водного транспорту), працівників бібліотеки 59 Будинку офіцерів м. Одеса, Подільського міського краєзнавчого музею та Роздільнянського районного історико-краєзнавчого музею, а також представників громадської організації «Об’єднання краєзнавців Миколаївського району «Світовид». На сьогодні ресурс містить понад 400 оцифрованих карт і схем різних років видання, близько 600 електронних книжок з історії краю, зокрема майже 200 ексклюзивних, представлених лише тут, більше понад 100 електронних публікацій, присвячених видатним мешканцям регіону, фото і відеоматеріали.

32020 року ГО «Краєвєд» співпрацює з Асоціацією географії та етнології Академії наук Молдови. Завдяки партнерствуміж організаціями на краєзнавчому ресурсі були вперше представлені цифрові аналогипрацьсучасних європейських науковців С. Шлегеля (Інститут соціальної антропології Макса Планка, Німеччина), Д. Лозовану (Асоціація географії та етнології Академії наук Молдови, Державний музей етнографії та природознавства Молдови), Т. Каала (Австрійська акаде- 
мія наук), В. Кюркчу (Комратський державний університет, Головне управління економічного розвитку, торгівлі та сфери послуг Гагаузії) та ін., які займаються вивченням південних регіонів України та суміжних земель у вимірі географії, етнографії, картографії, економічної та соціальної історії, міжнародних відносин.

На значенні створення таких краєзнавчих електронних ресурсів, зокрема для проведення наукових досліджень, наголошує Ю. Р. Москальова (2018), за висновком якоїпредставлені там в електронному вигляді писемні джерела можуть бути залучені до аналізу, незважаючи на недостатньо розроблену методику їх опрацювання (с. 42). На думку дослідниці, такі інтернет-ресурси, як «Краєвєд», певною мірою здатні компенсувати брак джерел, спричинений різного роду адміністративно-територіальними змінами, нововведеннями у справах документування та документообігу, війнами, які негативно позначилися на збереженості та цілісності документального масиву.

32018 року краєзнавчу електронну бібліотеку «Краєвєд» як рекомендований електронний інформаційний ресурс включено кафедрою економічної та соціальної географії і туризму геолого-географічного факультету Одеського національного університету ім. I. І. Мечникова до робочої програми 3 навчальної дисципліни «Екскурсологія» в розділі рекомендованої літератури. Зауважимо, що сам ресурс було сформовано лише у 2015 році, проте завдяки «планомірному оновленню інформаційного простору культурно-значимими і цікавими колекціями для розширення і збільшення різноманітності представлених матеріалів» (Іванова, 2011) усього впродовж двох років відбулась його інтеграція в освітній інформаційний простір регіону.

Також у методичному посібнику з питань впровадження програми патріотичного виховання для навчальних закладів і громадських об'єднань, передбачених в обласній цільовій комплексній програмі національно-патріотичного виховання дітей та молоді на 2016-2020 роки, затвердженої Департаментом освіти та науки Одеської обласної державної адміністрації, «Краєвєд» було рекомендовано як електронний інформаційний ресурс, що містить документальні матеріали з історії розвитку Одещини.

Більш активному залученню інформаційних матеріалів, представлених на краєзнавчих електронних ресурсах, в освітній процес сприятиме розробка відповідних методичних рекомендацій, які міститимуть конкретні поради і приклади ефективного використання представлених на таких ресурсах письмових джерел під час викладання різних навчальних дисциплін, починаючи з історії і літератури, і закінчуючи математикою та інженерною справою. Розробка таких рекомендацій може бути здійснена в рамках спільних проєктів бібліотек і закладів вищої освіти.

\section{ВИСНОВКИ}

Цифрова трансформація бібліотек дає змогу перейти на якісно новий ступінь збереження та презентації історико-культурної спадщини. Водночас важливим завданням залишається сприяння інтеграції інформації історико-культурних джерел у широкий суспільний обіг, зокрема в освітній процес.

Відповідно, особливого значення набуває процес взаємодії та співробітництва бібліотек із закладами освіти й науковими установами. Така взаємодія із залученням інформаційного потенціалу різних документно-інформаційних інсти- 
туцій (музеїв, архівів) та громадських організаційдає змогу не лише сформувати авторитетний краєзнавчий інформаційний ресурс, а й успішно інтегрувати його в освітній інформаційний простір.

Представлена краєзнавчими електронними бібліотеками інформація може виступати цінним джерелом під час вивчення історії, географії, літератури, мистецтва, архітектури, туризму, інженерної справи, екології та ін.

Створення краєзнавчих електронних ресурсів, зацікавленість користувачів у представленій на них інформації та її використанні під час навчання і досліджень засвідчують важливість краєзнавчого контенту, покликаного сприяти формуванню історико-культурної ідентичності регіону в контексті історії країни та формуванню національної історичної пам’яті в органічному поєднанні з розвитком історичної думки.

Узагальнення зарубіжного досвіду і перспективних вітчизняних практик використання в освітньому процесі краєзнавчих електронних бібліотечних ресурсів дає змогу обгрунтувати корпоративну та міжінституційну колаборацію як ефективний підхід у реалізації таких проєктів.

Інтенсивний розвиток цифрових бібліотечних проєктів в освітньому середовищі відкриває додаткові шляхи для реалізації завдань бібліотек із забезпечення широкого доступу користувачів до краєзнавчих інформаційних джерел та максимального розкриття їх інформаційного потенціалу.

\section{СПИСОК ПОСИЛАНЬ}

Беззуб І. Електронні бібліотеки в сучасній освіті. Наукові праці Національної бібліотеки України ім. В. І. Вернадського. 2015. Вип. 41. С. 479-495.

Бейнбридж Д., Виттен И., Николс Д. Электронные библиотеки в образовании. Москва: Обучение-Сервис, 2007. 248 с.

Бондар Л. М., Киричок І. В., Левашова О. Л. Електронні бібліотеки як елемент якості вищої освіти. Управління, економіка та забезпечення якості в фармації. 2015. № 1. С. 42-46.

Бруй О. Як діджиталізувати бібліотечну систему й не наробити помилок. Читомо. 2021. 20 квітня. URL: https://chytomo.com/iak-didzhytalizuvaty-bibliotechnu-systemu-j-nenarobyty-pomylok/ (дата звернення: 25.10.2021).

Денисенко С. О. Інтеграція краєзнавчих фондів бібліотек регіону в умовах інформатизації : автореф. дис.... канд. пед. наук : 07.00.08 / Харків. держ. акад. культури. Харків, 2003. 22 с.

Дікунова О. А. Формування системи бібліографічних електронних ресурсів з краєзнавства (на прикладі бібліотеки Криворізького державного педагогічного університету). Сучасні завдання та пріоритети діяльності бібліотек вищих навчальних закладів: шлях інновацій : матеріали наук.-практ. інтернет-конф. (Ужгород, 15-19 черв. 2020 р.) / ДВНЗ «Ужгород. нац. ун-т», Наук. б-ка. Ужгород, 2020. URL: https://dspace.uzhnu.edu. ua/jspui/handle/lib/29401 (дата звернення: 25.10.2021).

Іванова С. М. Тенденції використання електронних бібліотек в наукових і навчальних закладах (зарубіжний і вітчизняний досвід). Інформаційні технології і засоби навчання. 2011. № 23(3). URL: https://journal.iitta.gov.ua/index.php/itlt/article/view/500/419 (дата звернення: 25.10.2021).

Іванова С. М., Новицька Т. Л. Методика використання наукових електронних бібліотек для розвитку інформаційно-дослідницької компетентності наукових і науково-педагогічних працівників. Наукові записки. Серія: Педагогічні науки. 2019. Вип. 183. С. 89-95. 
Каращук О. Бібліотека в сучасному інформаційному просторі. Наукові праці Національної бібліотеки України ім. В. І. Вернадського. 2016. Вип. 43. С. 596-610.

Коваль Т., Лопата О. Перспективи розвитку національних книгозбірень в епоху цифрового суспільства (за матеріалами визначальних документів UNESCO, IFLA, AALL, ALA, LIBER, WSIS). Бібліотечний вісник. 2021. № 2. С. 3-16.

Краєзнавча робота в бібліотеках України: інформ. бюлетень. Вип. 30 / Нац. іст б-ка України ; підгот.: В. П. Кисельова, О. В. Покропивна ; ред. О. В. Михайлова. Київ, 2019. 83 с.

Кузнецова М. Класифікація бібліотечних електронних ресурсів з краєзнавства як платформа функціонування їхньої цілісної системи. Вісник Кншжкової палати. 2009. № 6. C. 24-28.

Кучерук О. А., Караман С. О., Караман О. В. Науково-освітні електронні бібліотеки у фаховій підготовці майбутніх учителів-словесників. Інформаційні технології і засоби навчання. 2018. Т. 65, № 3. С. 152-165.

Кушнаренко Н. М. Стратегічні напрями краєзнавчої діяльності бібліотек в умовах електронного середовища. Бібліотечне краєзнавство: нові технології : матеріали міжнар. семінару (Харків, 22-23 берез. 2005 р.) / Міністерство культури і туризму, Харків. держ. наук. б-ка ім. В. Г. Короленка ; уклад. Н. І. Полянська. Харків, 2005. С. 4-10.

Литвиненко Н. Краєзнавчо-бібліографічний контент веб-сайтів бібліотек Донбасу як складова краєзнавчої електронної бібліотеки. Вісник Книжкової палати. 2009. № 7. С. 39-42.

Лобузін І. В. Цифрові бібліотечні проекти: технологічні рішення та управління життєвим циклом колекцій: монографія. Київ: НБУВ, 2016. 216 с.

Лобузіна К. Технології організації знаннєвих ресурсів у бібліотечно-інформаційній діяльності: монографія. Київ: НБУВ, 2012. 252 с.

Москальова Ю. Р. Джерела до вивчення дитячої безпритульності та бездоглядності на Півдні України (60-і pp. XVIII - початок XX ст.) : дис. ... канд. іст. наук : 07.00 .06 / Донец. нац. ун-т ім. Василя Стуса. Вінниця, 2018. 283 с.

Новальська Т. В. Вивчення читача в українському бібліотекознавстві (друга половина XIX початок XXI століття) : автореф. дис.... д-ра іст. наук : 07.00 .08 / Нац. б-ка України ім. В. І. Вернадського. Київ, 2007. 40 с.

Островська О. М. Нові можливості доступу до науково-інформаційних ресурсів бібліотек України. Бібліотека. Наука. Комунікація. Розвиток бібліотечно-інформаційного потенціалу в умовах цифровізації : матеріали Міжнар. наук. конф. (6-8 жовт. 2020 р.) / НАН України, Нац. б-ка України ім. В. І. Вернадського, Асоц. б-к України, Рада дир. наук. б-к та інформ. центрів акад. наук - членів МААН ; відп. за вип. М. В. Іванова. Київ, 2020. С. 217-220.

Пасмор Н. П. Електронні бібліотеки як елемент інформаційного суспільства: консенсусні рішення. Імперативи розвитку електронних бібліотек: pro et contra : матеріали Міжнар. веб-конф. (м. Харків, 27 берез. 2014 р.) / Нац. юрид. ун-т ім. Ярослава Мудрого, Наук. б-ка, Харків. нац. ун-т ім. В. Н. Каразіна, Центр. наук. б-ка ; [за заг. ред. Н. П. Пасмор]. Харків, 2014. URL: http://library.nulau.edu.ua/biblioteka/Web-konf-2014/ Statti_Tezu/Pasmor.doc (дата звернення: 25.10.2021).

Пасмор Н. П. Цифрові сервіси е-науки: бібліотечний контекст. Регіональні інноваційні ініціативи: завдання та шляхи вирішення: зб. наук. пр. за матеріалами Круглого столу (м. Харків, 5 квіт. 2019 року) / редкол. С. В. Глібко, А. М. Любчич, О. Ю. Палант. Харків : НДІ ПЗІРНАПрНУкраїни, 2019. С. 97-103.

Рибачок О. Європейська цифрова бібліотека (Європіана): створення та пріоритети розвитку (2000-2020). Бібліотечний вісник. 2017. № 2. С. 8-16.

Скрипка Л. І., Бондаренко О. М., Фоменко О. Л. Електронна бібліотека в системі дистанційної освіти вищого навчального закладу. Проблеми і перспективи розвитку освіти. Організація дистанційної освіти у загальноосвітній та вищий школі : зб. ст. Всеукр. наук. конф. 15-16 січ. 2016 р. Дніпропетровськ, 2016. С. 110-117. 
Соловяненко Д. Онлайновий бібліотечний сервіс як один із видів бібліотечного сервісу. Наукові праці Національної бібліотеки України ім. В. І. Вернадського. 2003. Вип. 11. C. 200-222.

Тенденції впливу глобального інформаційного середовища на соціокультурну сферу України : монографія / О. С. Онищенко, В. М. Горовий, В. І. Попик, Ю. М. Половинчак, Л. Й. Костенко, В. М. Удовик, А. В. Матвійчук, О. В. Ворошилов, В. Ю. Омельчук, Л. С. Новосьолова, Н. В. Посмітна. Київ : НБУВ, 2013. 197 с.

Топольник Я. В. Специфічні особливості та функціональні можливості електронної бібліотеки. Проблеми реформування педагогічної науки та освіти : матеріали Міжнар. наук.-практ. конф. (м. Хмельницький, 1-2 груд. 2017 р.). Херсон, 2017. С. 185-188.

Чала О. В. Сучасний підхід до періодизації краєзнавства в Україні. Вісник ЛНУ імені Тараса Шевченка. 2017. № 7. С. 259-270.

Ярошенко Т. О. Організація та управління електронними ресурсами в сучасній бібліотеці. Бібліотекознавство. Документознавство. Інформологія. 2008. № 3. С. 13-21.

Abrizah A., Zainab A. N. Collaborative Digital Library for Historical Resources: Defining The System's Artifacts Using Zachman's Approach. The Sixth International Conference on Information Integration and Web Based Applications \& Services. 2004. P. 335-345.

Abrizah A., Zainab A. N. Collaborative Digital Library of Historical Resources: Evaluation of First Users. Malaysian Journal of Library \& Information Science.2007. Vol. 12, № 2. P. 99-122.

Clarke W., Lee J. The Promise of Digital History in the Teaching of Local History. The Clearing House. 2004. Vol. 78, № 2. P. 84-87.

Galloway E. Historic Pittsburgh Website. 2005. URL: https://rum.lib.umd.edu/bitstream/ handle/1903/12952/historicpittsburghwebsite.pdf?sequence=1 (accessed: 25.10.2021)

Galloway E. A. Imaging Pittsburgh: Creating a Shared Gateway to Digital Image Collections of the Pittsburgh Region. First Monday. 2004. Vol. 9, № 5. URL: https://journals.uic.edu/ojs/ index.php/fm/article/download/1141/1061 (accessed: 25.10.2021).

Lee J., Molebash Ph. Using Digital History for Positive Change in Social Studies Education. Journal of Computing in Teacher Education. 2004. Vol. 20, № 4. P. 153-157.

Mendel J. M. Education Using Digital Libraries. WTEC Panel Report on Digital Information Organization in Japan. 1999. P. 13-22.

Nartschik S. Gutenberg in Tokyo. Japanstudien. 2006. Vol. 17, № 1. P. 189-208.

Sonker S. K., Mahawar K. L. Digital Library: Processes, Services, Challenges and Opportunities. 2017. URL: https://drtc.isibang.ac.in/ldl/bitstream/handle/1849/390/p78_sharad-sonker. pdf (accessed: 25.10.2021).

Welcome to the «Europeanain Your Classroom: Building 21st-Century Competences with Digital Cultural Heritage (Rerun)» MOOC. European Schoolnet Academy. 2020. URL: https://www. europeanschoolnetacademy.eu/courses/course-v1:Europeana+Culture_EN+2020/about (accessed: 25.10.2021).

Yu H., Breivold S. Electronic Resource Management in Libraries : Research and Practice. Hershey ; New York : Information Science Reference, 2008. XXII, 416 p. DOI:10.4018/978-1-59904-891-8.

Zellers J., Adams T. M., Hill K. The ABCs of ERM: Demystifying Electronic Resource Management for Public and Academic Librarians. Santa Barbara : ABC-CLIO Libraries Unlimited, 2018. 244 p.

\section{REFERENCES}

Bezzub, I. (2015). Elektronni biblioteky v suchasnii osviti [Electronic libraries in modern education]. Naukovi pratsi Natsionalnoi biblioteky Ukrainy imeni V. I. Vernadskoho, 41, 479495 [in Ukrainian].

Bainbridge, D., Vitten, I., \& Nikols, D. (2007). Elektronnye biblioteki v obrazovanii [Digital Libraries in Education]. Obuchenie-Servis [in Russian]. 
Bondar, L. M., Kyrychok, I. V. \& Levashova, O. L. (2015). Elektronni biblioteky yak element yakosti vyshchoi osvity [Electronic libraries as an element of quality of higher education]. Management, economy and quality assurance in pharmacy, 1, 42-46 [in Ukrainian].

Bruy, O. (2021, April 20). Yak didzhytalizuvaty bibliotechnu systemu y ne narobyty pomylok [How to digitalize the library system and not make mistakes]. Chytomo. https://chytomo.com/iakdidzhytalizuvaty-bibliotechnu-systemu-j-ne-narobyty-pomylok/ [in Ukrainian].

Denysenko, S. O. (2003). Intehratsiia kraieznavchykh fondiv bibliotek rehionu $v$ umovakh informatyzatsii [Integration of Local Lore Funds of Libraries of the Region in the Conditions of Informatization] [Abstract of PhD Dissertation, Kharkiv State Academy of Culture] [in Ukrainian].

Dikunova, O.A.(2020, June 15-19). Formuvannia systemy bibliohrafichnykh elektronnykh resursiv z kraieznavstva (na prykladi biblioteky Kryvorizkoho derzhavnoho pedahohichnoho universytetu) [Formation of a system of bibliographic electronic resources on local lore (on the example of the library of Kryvyi Rih State Pedagogical University)] In Suchasni zavdannia ta priorytety diialnosti bibliotek vyshchykh navchalnykh zakladiv: shliakh innovatsii [Modern Tasks and Priorities of Libraries of Higher Educational Institutions: the Way of Innovations], Proceedings of the Scientific and Practical Web-Conference, Uzhhorod, Ukraine. Scientific Library of Uzhhorod National University [in Ukrainian]. https://dspace. uzhnu.edu.ua/jspui/handle/lib/29401.

Ivanova, S. M. (2011). Tendentsii vykorystannia elektronnykh bibliotek v naukovykh i navchalnykh zakladakh (zarubizhnyi i vitchyznianyi dosvid) [Trends in the use of electronic libraries in scientific and educational institutions (foreign and domestic experience)]. Information Technologies and Learning Tools, 23(3). https://journal.iitta.gov.ua/index.php/itlt/article/ view/500/419 [inUkrainian].

Ivanova, S. M., \& Novytska, T. L. (2019). Metodyka vykorystannia naukovykh elektronnykh bibliotek dlia rozvytku informatsiino-doslidnytskoi kompetentnosti naukovykh i naukovo-pedahohichnykh pratsivnykiv [Methods of using scientific electronic libraries for the development of information and research competence of scientific and scientific-pedagogical workers]. Academic notes Series: Pedagogical Sciences, 183, 89-95 [in Ukrainian].

Karashchuk, O. (2016). Biblioteka v suchasnomu informatsiinomu prostori [Library in the modern information space.]. Academic Papers of the Vernadsky National Library of Ukraine, 43, 596-610 [in Ukrainian].

Koval, T. \& Lopata, O. (2021). Perspektyvy rozvytku natsionalnykh knyhozbiren v epokhu tsyfrovoho suspilstva (za materialamy vyznachalnykh dokumentiv UNESCO, IFLA, AALL, ALA, LIBER, WSIS) [Prospects for the development of national book collections in the digital age (according to the defining documents of UNESCO, IFLA, AALL, ALA, LIBER, WSIS)]. Bibliotečnij visnik, (2), 3-16 [in Ukrainian].

Kyselova, V. P., \& Pokropyvna, O. V. (2019). Kraieznavcha robota v bibliotekakh Ukrainy [Local Lore Work in Libraries of Ukraine] (edited by O. V Mykhailova, Iss. 30). National Historical Library of Ukraine [in Ukrainian].

Kuznetsova, M. (2009). Klasyfikatsiia bibliotechnykh elektronnykh resursiv z kraieznavstva yak platforma funktsionuvannia yikhnoi tsilisnoi systemy [Classification of library electronic resources on local lore as a platform for the functioning of their holistic system]. Bulletin of the Book Chambe, (6), 24-28 [in Ukrainian].

Kucheruk, O. A., Karaman, S. O., \& Karaman, O. V. (2018). Naukovo-osvitni elektronni biblioteky $\mathrm{u}$ fakhovii pidhotovtsi maibutnikh uchyteliv-slovesnykiv [Scientific and educational electronic libraries in the professional training of future teachers of vocabulary]. Information Technologies and Learning Tools, 65(3), 152-165 [in Ukrainian].

Kushnarenko, N. M. (2005, March 22-23). Stratehichni napriamy kraieznavchoi diialnosti bibliotek v umovakh elektronnoho seredovyshcha [Strategic directions of local lore 
activity of libraries in the conditions of electronic environment]. In N. I. Polianska (Comp.), Bibliotechne kraieznavstvo: novi tekhnolohii [Library Local Lore: New Technologies], Proceedings of the International Seminar (pp.4-10), Kharkiv, Ukraine. Kharkiv Korolenko State Scientific Library [in Ukrainian].

Lytvynenko, N. (2009). Kraieznavcho-bibliohrafichnyi kontent veb-saitiv bibliotek Donbasu yak skladova kraieznavchoi elektronnoi biblioteky [Local lore and bibliographic content of websites of libraries of Donbass as a component of local lore electronic library]. Bulletin of the Book Chambe, (7), 39-42 [in Ukrainian].

Lobuzin, I.V. (2016). Tsyfrovi bibliotechni proekty: tekhnolohichni rishennia ta upravlinnia zhyttievym tsyklom kolektsii [Digital Library Projects: Technological Solutions and Collection Lifecycle Management] [Monograph]. V. I. Vernadskyi National Library of Ukraine [in Ukrainian].

Lobuzina, K. (2012). Tekhnolohii orhanizatsii znannievykh resursiv u bibliotechno-informatsiinii diialnosti [Technologies of Organization of Knowledge Resources in Library and Information Activity] [Monograph]. V. I. Vernadskyi National Library of Ukraine [in Ukrainian].

Moskalova, Yu. R. (2018). Dzherela do vyvchennia dytiachoi bezprytulnosti ta bezdohliadnosti na Pivdni Ukrainy (60-i rr. XVIII - pochatok XX st.) [Sources for the Study of Child Homelessness and Neglect in Southern Ukraine (60's XVIII - Early XX Century)] [PhD Dissertation, Vasyl Stus Donetsk National University] [in Ukrainian].

Novalska, T. V. (2007). Vyvchennia chytacha v ukrainskomu bibliotekoznavstvi (druha polovyna XIXpochatok XXI stolittia) [Study of the Reader in Ukrainian Library Science (Second Half of the 19th -Beginning of the 21st Century)] [Abstract of DSc Dissertation, Vernadsky National Library of Ukraine] [in Ukrainian].

Ostrovska, O. M. (2020, October 6-8). Novi mozhlyvosti dostupu do naukovo-informatsiinykh resursiv bibliotek Ukrainy [New opportunities for access to scientific and information resources of libraries of Ukraine]. In M. V. Ivanova (Ed.), Biblioteka. Nauka. Komunikatsiia. Rozvytok bibliotechno-informatsiinoho potentsialu v umovakh tsyfrovizatsii [Library. Science. Communication. Development of Library and Information Potential in the Conditions of Digitalization], Proceedings of the International Conference (pp. 217-220), Kiev, Ukraine. Vernadsky National Library of Ukraine [in Ukrainian].

Pasmor, N. P. (2014, March 27). Elektronni biblioteky yak element informatsiinoho suspilstva: konsensusni rishennia [Electronic libraries as an element of the information society: consensus solutions]. In N. P. Pasmor (Ed.), Imperatyvy rozvytku elektronnykh bibliotek: pro et contra [Imperatives of electronic library development: pro et contra], Proceedings of International Web-Conference, Kharkiv, Ukraine. Scientific Library of Yaroslav the Wise National Law University. http://library.nlu.edu.ua/biblioteka/Web-konf-2014/ Imperatives.pdf [in Ukrainian].

Pasmor, N. P. (2019, April 5). Tsyfrovi servisy e-nauky: bibliotechnyi kontekst [Digital e-science services: library context.]. In S. V. Hlibko, A. M. Liubchych, O. Yu. Palant (Eds.), Rehionalni innovatsiini initsiatyvy: zavdannia ta shliakhy vyrishennia [Regional Innovation Initiatives: Tasks and Solutions], Proceedings of the Roundtable Conference (pp. 97-103), Kharkiv, Ukraine. Scientific and Research Institute of Providing Legal Framework for the Innovative Development of National Academy of Law Sciences of Ukraine [in Ukrainian].

Rybachok, O. (2017). Yevropeiska tsyfrova biblioteka (Ievropiana): stvorennia ta priorytety rozvytku (2000-2020) [European Digital Library (Europeana): Creation and Development Priorities (2000-2020)]. Bibliotečnij visnik, (2), 8-16 [in Ukrainian].

Skrypka, L. I., Bondarenko, O. M., \& Fomenko O. L. (2016, January 15-16). Elektronna biblioteka v systemi dystantsiinoi osvity vyshchoho navchalnoho zakladu [Electronic library in the system of distance education of higher education institution]. In Problemy i perspektyvy rozvytku osvity. Orhanizatsiia dystantsiinoi osvity u zahalnoosvitnii ta vyshchyi shkoli [Problems and Prospects of Education Development. Organization of Distance Education 
in Secondary and Higher School], Proceedings of the All-Ukrainian Scientific Conference (pp. 110-117), Dnipropetrovsk, Ukraine. Global Nauka [in Ukrainian].

Solovianenko, D. (2003). Onlainovyi bibliotechnyi servis yak odyn iz vydiv bibliotechnoho servisu [Online library service as one of the types of library service]. Academic Papers of the Vernadsky National Library of Ukraine, 11, 200-222 [in Ukrainian].

Onyshchenko, O. S., Horovyi, V. M., Popyk, V. I., Polovynchak, Yu. M., Kostenko, L. Y., Udovyk, V. M., Matviichuk, A. V., Voroshylov, O. V., Omelchuk, V. Yu., Novosolova, L. S., \& Posmitna, N. V. (2013). Tendentsii vplyvu hlobalnoho informatsiinoho seredovyshcha na sotsiokulturnu sferu Ukrainy [Trends in the Impact of the Global Information Environment on the Socio-cultural Sphere of Ukraine] [Monograph]. Vernadsky National Library of Ukraine [in Ukrainian].

Topolnyk, Ya. V. (2017, December 1-2). Spetsyfichni osoblyvosti ta funktsionalni mozhlyvosti elektronnoi biblioteky [Specific features and functionality of the electronic library]. In Problemy reformuvannia pedahohichnoi nauky ta osvity [Problems of reforming pedagogical science and education], Proceedings of the International Scientific-practical Conference (pp. 185-188), Khmelnytsky, Ukraine. Helvetyka [in Ukrainian].

Chala, O. V. (2017). Suchasnyi pidkhid do periodyzatsii kraieznavstva v Ukraini [A modern approach to the periodization of local lore in Ukraine.]. Bulletin of Luhansk Taras Shevchenko National University, (7), 259-270 [in Ukrainian].

Yaroshenko, T. O. (2008). Orhanizatsiia ta upravlinnia elektronnymy resursamy v suchasnii bibliotetsi [Organization and management of electronic resources in a modern library]. Bibliotekoznavstvo. Dokumentoznavstvo. Informolohiia, (3), 13-21 [in Ukrainian].

Abrizah, A., \& Zainab, A. N. (2004). Collaborative Digital Library for Historical Resources: Defining the System's Artefacts Using Zachman's Approach. In The Sixth International Conference on Information Integration and Web Based Applications \& Services (pp. 335-345) [in English].

Abrizah, A., \& Zainab, A. N. (2007). Collaborative Digital Library of Historical Resources: Evaluation of First Users. Malaysian Journal of Library \& Information Science, 12(2), 99-122 [in English].

Clarke, W., \& Lee, J. (2004). The Promise of Digital History in the Teaching of Local History. The Clearing House, 78(2), 84-87 [in English].

Galloway, E. (2005). Historic Pittsburgh Website. https://drum.lib.umd.edu/bitstream/ handle/1903/12952/historicpittsburghwebsite.pdf?sequence=1 [in English].

Galloway, E. A. (2004). Imaging Pittsburgh: Creating a Shared Gateway to Digital Image Collections of the Pittsburgh Region. First Monday, 9(5). https://journals.uic.edu/ojs/index.php/fm/ article/download/1141/1061 [in English].

Lee, J., \& Molebash, Ph. (2004). Using Digital History for Positive Change in Social Studies Education. Journal of Computing in Teacher Education, 20(4), 153-157 [in English].

Mendel, J. M. (1999). Education Using Digital Libraries. WTEC Panel Report on Digital Information Organization in Japan, 13-22 [in English].

Nartschik, S. (2006). Gutenberg in Tokyo. Japanstudien, 17(1), 189-208 [in Germany].

Sonker, S. K., \& Mahawar, K. L. (2017). Digital Library: Processes, Services, Challenges and Opportunities. https://drtc.isibang.ac.in/ldl/bitstream/handle/1849/390/p78_sharadsonker.pdf [in English].

European Schoolnet Academy. (2020). Welcome to the "Europeana Your Classroom: Building 21st-Century Competences with Digital Cultural Heritage (Rerun)" MOOC. https://www. europeanschoolnetacademy.eu/courses/course-v1:Europeana+Culture_EN+2020/about [in English].

Yu H., \& Breivold, S. (2008). Electronic Resource Management in Libraries: Research and Practice. Information Science Reference [in English].

Zellers, J., Adams, T. M., \& Hill, K. (2018). The ABCs of ERM: Demystifying Electronic Resource Management for Public and Academic Librarians. ABC-CLIO Libraries Unlimited [in English]. 
UDC 021.2:[002.1:908]:004

\author{
Yevhen Zabiianov, \\ Leading Librarian, \\ Hrushevsky Odesa Regional Universal Scientific \\ Library (Odesa, Ukraine) \\ e-mail:j_zb@ukr.net \\ ORCID: 0000-0002-4959-9099
}

\title{
LOCAL HISTORICAL E-RESOURCES IN THE EDUCATIONAL PROCESS
}

Digitization and mediatization of information raise the issue of user access to electronic information resources. Given the need to form and strengthen the regional and national identity, study and promote historical and local lore information and providing access to it, the integration of such information into educational practices to master it by young people has become more important.

The article is devoted to the coverage and substantiation of effective approaches to using local lore electronic resources in the educational process.

During the research, the descriptive method, methods of comparison and generalization concerning the experience of use in the field of education of local lore electronic resources of libraries were used. The methods of included observation and periodic monitoring, applied during the development and maintenance of the functioning with the participation of the author of the local history resource "Kraeved" (kraeved.od.ua) (starting from 15.03.2020), proved to be effective. An analytical and survey method was used to analyse the available theoretical work on the research topic.

The novelty of the obtained results lies in the coverage and substantiation of the specifics of the use of electronic local history information resources in the educational process in different countries, in particular during the study of students of historical specialties, and some countries students majoring in cultural studies and art history. The most comprehensive electronic local history information resources are used in the United States, where their historical and local history content attracts not only teachers and students but also a wider range of users: genealogists, writers, engineers, urban planners, architects, realtors and documentary filmmakers.

The obtained results of the research testified to the tendency to use library local lore electronic information resources in the educational process. Their creation, interest of users in the information presented on them and its use during training testify to the importance of local lore content designed to promote the formation of the historical and cultural identity of the region in the context of national history and the formation of national historical memory in combination with historical thought. The generalization of foreign experience and perspective domestic practices of using local library electronic resources in the educational process allows substantiating effective approaches to the organization of such activities, intensification of involvement of domestic library local lore electronic information resources in solving information problems related to educational activities. The intensive development of digital library projects in the educational environment will open additional ways to implement the tasks of libraries to ensure wide access of users to local history information sources and the maximum disclosure of their information potential.

Keywords: local lore electronic resources, information and educational process, local lore content, educational institutions, national historical memory, historical and cultural identity of the region.

Стаття надійшла до редакції 11.10.2021 p. 